\title{
Investigating Jurors in the Digital Age: One Click at a Time
}

\author{
Thaddeus Hoffmeister ${ }^{*}$
}

\section{INTRODUCTION}

In the eyes of many attorneys, the trier of fact, not the evidence presented, is the key factor in determining the outcome of a trial. ${ }^{1}$ Thus, attorneys have long sought to learn as much as possible about those deciding the fate of their clients. ${ }^{2}$ While information has been readily available about judges who have established reputations and regularly decide cases, ${ }^{3}$ one cannot say the same for jurors who are randomly drawn from the community to hear one case. Traditionally, attorneys had to expend significant time and resources to discover information about jurors. ${ }^{4}$ The Digital Age, however, has changed this.

Attorneys can now discover information about jurors in seconds or minutes as people place more and more personal information online. ${ }^{5}$

* Associate Professor of Law, University of Dayton School of Law; editor of www.juries.typepad.com, a blog dedicated to the study of juries. The author would like to acknowledge the excellent work of his research assistant Mike Porter on this Article. This Article also benefited from thorough editing by the staff of the Kansas Law Review. Of course, any errors or mistakes in this Article are solely the responsibility of this Author.

1. John H. Blume, Sheri Lynn Johnson \& A. Brian Threlkeld, Probing "Life Qualification” Through Expanded Voir Dire, 29 HofSTRA L. REV. 1209, 1209 (2001) ("The conventional wisdom is that most trials are won or lost in jury selection.”); Steven C. Serio, Comment, A Process Right Due? Examining Whether a Capital Defendant Has a Due Process Right to a Jury Selection Expert, 53 AM. U. L. REV. 1143, 1147 (2004) ("Many scholars believe that most capital cases are won or lost during jury selection.”).

2. See infra Part II.A.

3. See Bracy v. Gramley, 81 F.3d 684, 688 (7th Cir. 1996), rev’d Bracy v. Gramley, 520 U.S. 899 (1997), and vacated sub nom. Collins v. Welborn, 520 U.S. 1272 (1997) ("There are prosecution-minded judges, and defense-minded judges....”); see also History of the Federal Judiciary, FED. JUD. CENTER, http://www.fjc.gov/history/home.nsf/page/judges.html (last visited Nov. 22, 2011) (providing biographical information on all federal judges). Many states have similar websites. See, e.g., Judicial Directory, N.Y. ST. UNIFIED CT. SYS., http://www.nycourts.gov/ judges/directory.shtml (last visited Jan. 24, 2012).

4. See infra text accompanying notes 51-59.

5. See, e.g., Johnson v. McCullough, 306 S.W.3d 551, 558-59 (Mo. 2010) (en banc) (per curiam) (discussing the ease by which information about jurors may be discovered in light of technological advances); see also Stephen P. Laitinen \& Hilary J. Loynes, A New “Must Use” Tool 
The speed and ease by which information about jurors is now discovered online has led attorneys to increasingly investigate and research jurors. ${ }^{6}$ In fact, the practice has become fairly commonplace, with courts, ${ }^{7}$ practitioners, ${ }^{8}$ and state bar associations ${ }^{9}$ all approving and encouraging its use. One prominent trial consultant has even claimed that "[a]nyone who [does not] make use of [Internet searches] is bordering on malpractice." 10 While this may somewhat overstate the importance of investigating jurors online, it demonstrates just how routine the practice has become in certain areas of the country. ${ }^{11}$

Like with other aspects of litigation, the online investigation of jurors raises a few concerns. ${ }^{12}$ Some view the practice as overly intrusive because it allows attorneys to learn things about jurors that would rarely, if ever, come up or be discussed during voir dire. ${ }^{13}$ For example, judges generally prohibit attorneys from questioning a potential juror during

In Litigation?, FOR THE DEF., Aug. 2010, at 16, 16 ("People are putting more and more personal information on the Internet. In the United States, no less than 35 percent of adult Internet users and 66 percent of Internet users under the age of 30 have a profile on a social networking site.”).

6. See Lior Jacob Strahilevitz, Reputation Nation: Law in an Era of Ubiquitous Personal Information, 102 Nw. U. L. REV. 1667, 1688-94 (2008) (discussing the market that has arisen for jury consultants and the effect technology has had on the voir dire process).

7. See McCullough, 306 S.W.3d at 558-59 (holding that courts should allow parties reasonable time to research prospective jurors); Carino v. Muenzen, No. L-0028-07, 2010 WL 3448071, at*9-10 (N.J. Super. Ct. App. Div. Aug. 30, 2010) (per curiam) (discussing approvingly the use of the Internet by attorneys to gather information about prospective jurors during voir dire), cert. denied, 13 A.3d 363 (N.J. 2011) (table decision).

8. See Julie Kay, Social Networking Sites Help Vet Jurors, LAW TECH. NEWS (ONLINE), Aug. 13, 2008, available at http://www.law.com/jsp/lawtechnologynews/PubArticleLTN.jsp?id=1202423 $725315 \&$ slreturn=1 (discussing the views of attorneys on the use of the Internet to investigate prospective jurors); Jack Zemlicka, Social Distortion, WIS. L.J. (May 10, 2010), http://wislawjournal.com/2010/05/10/social-distortion/ ("Since the explosion of social networking, [one Wisconsin attorney] regularly researches jurors and monitors their online activity during lengthy trials. [As this attorney explained,] 'It's not unusual for someone in my office to run the name of a juror, if we get them ahead of time, through Google, Twitter or Facebook.’”).

9. See NYCLA Comm. on Prof'l Ethics, Formal Op. 743 (2011) (discussing a lawyer’s investigation of jurors' Internet and social networking postings during the course of a trial).

10. Carol J. Williams, Jury Duty? May Want to Edit Online Profile, L.A. TimES, Sept. 29, 2008, at A6 (third alteration in original) (internal quotation marks omitted).

11. Some trial consultants offer "personality profiling" of jurors based on Internet research. Julie Kay, Vetting Jurors Via MySpace, NAT’L L.J., Aug. 11, 2008, at 1.

12. See Jamila A. Johnson, Voir Dire: To Google or Not to Google, 5 GPSOLO LAW TRENDS \& NEWS: LITIG. (2008), available at http://www.americanbar.org/newsletter/publications/law_trends_ news_practice_area_e_newsletter_home/litigation_johnson.html (describing how researching jurors online could rise to the level of jury tampering or improper influence if an attorney is not careful).

13. See NANCY S. MARDER, The JuRy Process 82-83 (2005) ("For example, lawyers have sometimes wanted to ask prospective jurors about their religion or sexual orientation during voir dire, but judges have usually denied such inquiries on the ground that it is an intrusion into the juror's privacy and not necessary for the parties to know.”). 
voir dire about her political ideology or voting history. ${ }^{14}$ By going online, however, the attorney may discover a juror's past political contributions or current political affiliations. ${ }^{15}$

In addition to privacy concerns, questions arise surrounding full disclosure. Some believe that an attorney-depending on his interest in the dispute-may withhold certain disqualifying juror information from the court or opposing counsel. ${ }^{16}$ Consider a recent example from Michigan. ${ }^{17}$ Before the second day of a two-day criminal trial, a sitting juror posted the following on her Facebook account: "[A]ctually excited for jury duty tomorrow. It's gonna be fun to tell the defendant they're GUILTY."18 The defense discovered this posting prior to the start of the second day of trial and the court promptly dismissed the juror. ${ }^{19}$

One may easily envision a different outcome had the prosecutor discovered the information. A different defense attorney also might have taken an alternative approach to resolving this problem. Rather than report the misconduct to the judge and request dismissal of the juror, the defense attorney might have approached the prosecutor about a mid-trial plea deal ${ }^{20}$ or used the information to revamp her trial strategy. As this Article will explain, most attorneys do not have a legal or ethical obligation to turn over information about jurors. ${ }^{21}$ In addition, juror information is generally outside the scope of discovery. ${ }^{22}$

14. See, e.g., Connors v. United States, 158 U.S. 408, 411-15 (1895) (describing questions related to political affiliation and stating they were properly excluded during voir dire).

15. Several mainstream websites offer information about campaign contributions. See, e.g., Campaign Donors: Fundrace 2012, HuFFINGTON POST, http://fundrace.huffingtonpost.com (last visited Nov. 4, 2011) (providing an interactive map that allows users to search by a person's name or location for campaign contributions).

16. Correy Stephenson, Should Lawyers Monitor Jurors Online?, LegalNEws.com (Dec. 27, 2010), http://www.legalnews.com/macomb/1004089 (noting that one attorney "expressed concern that some attorneys might fail to disclose information they learn about a juror-keeping it in 'their back pocket' in case of an unfavorable verdict—and then use the information to seek a new trial").

17. Jameson Cook, Facebook Post Is Trouble for Juror, MACOMB DAILY, Aug. 28, 2010, http://www.macombdaily.com/articles/2010/08/28/news/doc4c79c743c66e8112001724.txt.

18. Id. (errors in original).

19. Id.

20. Mid-trial pleas or pleas right after jury empanelment occur in some instances. See, e.g., Barry Leibowitz, Muslim Convert Admits He Murdered U.S. Soldier, Plea Avoids Death Penalty, CBS NEwS (July 25, 2011, 5:52 PM), http://www.cbsnews.com/8301-504083_162-20083191504083.html ("Abdulhakim Muhammad pleaded guilty in the middle of his trial to capital murder and attempted capital murder charges.").

21. See infra Part IV.B (discussing attorneys' obligation to disclose disqualifying juror information).

22. See infra notes 253-55 and accompanying text (noting the narrowness discovery of juror information). 
The abovementioned example also illustrates that online juror investigations - unlike traditional investigations-now occur at various stages of trial. Further, attorneys today engage in the practice for reasons beyond just jury selection ${ }^{23}$ or identification of biased or unfavorable jurors. $^{24}$ Some attorneys use the practice in an effort to create a bond with the jurors. For instance, an attorney who discovers through her online investigation that a juror closely follows sports might incorporate athletic references or metaphors in the courtroom to better connect with that juror. ${ }^{25}$ Other attorneys, who find themselves on the losing side at the end of trial, use the practice to look for appealable issues. ${ }^{26}$ For example, an attorney might search a juror's blog or social networking site hoping to discover an inappropriate remark or comment made to or by the juror during trial. ${ }^{27}$

While much has been written about obtaining juror information through in-court voir dire, ${ }^{28}$ little has been offered about out-of-court methods like juror investigations. The legal academy has virtually ignored the topic of juror investigations. This author is aware of only one major academic work solely dedicated to this area of law in the past forty years. ${ }^{29}$ One may attribute this dearth of scholarship, at least in

23. This Article uses the term "jury selection." It should really be called "jury de-selection" because neither party has an affirmative right to empanel certain jurors. For a discussion on the theory of affirmative jury selection, see generally Deborah Ramirez, Affirmative Jury Selection: A Proposal to Advance Both the Deliberative Ideal and Jury Diversity, 1998 U. CHI. LEGAL F. 161.

24. See Kay, supra note 8 ("Some jury consultants and lawyers, however, still want to research their juries even after jury selection, for different reasons. For one thing, the information can be used to get a case overturned on appeal if it turns out a juror lied on a questionnaire. Additionally, some consultants and lawyers are beginning to use Internet information [they have] obtained about jurors to influence them during the trial, particularly during closing arguments.”).

25. See id. (noting that a lawyer might analogize to a juror's affiliations or interests to gain sympathy).

26. Id.

27. See infra notes 129-38 and accompanying text (citing examples of juror misconduct through blog posts).

28. See, e.g., Thomas J. Hurney Jr. \& Randal H. Sellers, Picking Juries: Questionnaires and Beyond, 75 DEF. Couns. J. 370, 370-71 (2008) (discussing the use of questionnaires during in-court voir dire); Mary R. Rose \& Shari Seidman Diamond, Judging Bias: Juror Confidence and Judicial Rulings on Challenges for Cause, 42 LAW \& SOC’Y REV. 513, 515-17 (2008) (discussing jurors' self-assessments of fairness during voir dire).

29. Joshua Okun, Investigation of Jurors By Counsel: Its Impact on the Decisional Process, 56 GEO. L.J. 839, 840 (1968). The issue, however, has received attention in material targeting practitioners. See, e.g., Eustace Cullinan \& Herbert W. Clark, PreParation for Trial of CIVIL ACTIONS 78-82 (3d ed. 1956) (advocating the use and legality of juror investigations); Jeffrey T. Frederick, You, the Jury, and the Internet, 39 BRIEF, Winter 2010, at 12, 16-18 ("The Internet is also a source for information on potential jurors for jury-selection purposes."); Clarence W. Heyl, Selection of the Jury, 40 ILL. B.J. 328, 333 (1952) (describing methods of juror investigation); 5 AM. 
some part, to the fact that over the past decades the practice of investigating jurors has occurred less frequently. ${ }^{30}$

The Digital Age, however, has reversed this trend. The Internet has resurrected the practice of investigating jurors. ${ }^{31}$ Thus, there is a growing need for more research and study on this topic to better understand its impact on the legal system and society as a whole. This Article attempts to fill the current void by taking an in-depth look at online juror investigations.

In Part II, this Article offers an overview of juror investigations by attorneys. Here, the Article focuses on the evolution of the practice. In Part III, the Article examines the benefits of the practice to both the legal system and attorneys. This Part demonstrates that more information about jurors improves the jury-selection process and reduces the likelihood of juror misconduct.

Part IV addresses the two main drawbacks associated with investigating jurors: juror privacy and full disclosure. In discussing juror privacy, this Article challenges the notion that the current methods of investigating jurors are overly intrusive. This Article then examines the issue of full disclosure and identifies it as an area ripe for reform. Finally, this Article, in Part V, analyzes two proposals that would require attorneys to reveal certain information discovered about jurors to either the court or opposing counsel.

\section{THE PROCESS}

\section{A. Historical Approach}

Obtaining information about jurors outside of the traditional voir dire process and prior to trial is not a new concept. ${ }^{32}$ The idea has been around for quite some time. As far back as 1708, the English Treason Act stated that "when any Person is indicted for High Treason ... a List ... of the Jury mentioning the Names[,] Profession[,] and Place of

JUR. Trials § 4, at 253 (1966) (instructing practitioners on methods of pretrial investigation of jurors).

30. Lisa Blue \& Robert B. Hirschhorn, Blue’s Guide to Jury Selection § 9:1 (C. Joseph Miles et al. eds., 2004) ("Drive-bys can be a valuable tool, but they seem to have fallen out of favor.").

31. Christopher B. Hopkins, Internet Social Networking Sites for Lawyers, 28 TRIAL ADVOC. Q., Spring 2009, at 12, 13-14.

32. Commonwealth v. Allen, 400 N.E.2d 229, 236 (Mass. 1980) ("The practice of permitting counsel to acquire information about prospective jurors in advance of trial . . . is long established.”). 
Abode of the ... Jurors [shall] be also given at the same Time that the Copy of the Indictment is delivered to the Party indicted." 33 In 1770, Blackstone commented about the practice of providing juror information to certain defendants. ${ }^{34}$

Borrowing from the English, American colonialists also afforded defendants early access to information about jurors in select cases. ${ }^{35}$ In 1790, Congress passed the Public Acts of the First Congress, which included provisions that gave defendants facing capital or treason charges the right to access and investigate the jury venire list at least three days before trial. ${ }^{36}$ The purpose of the statute was twofold. First, it "put the defendant on an even plane with the government in preparing for his defense by giving him the names of the attending jurors." ${ }^{37}$ Second, the statute provided the defendant the opportunity to discover information about potential jurors. ${ }^{38}$

By the twentieth century, many attorneys became increasingly dissatisfied with the limited information that courts provided and started investigating jurors on their own. Both prosecutors and defense attorneys engaged in the practice, ${ }^{39}$ and courts generally approved of the tactic. $^{40}$ During the 1907 trial of Henry Thaw, "detectives in the employ of the District Attorney and of the defense" conducted extensive searches into the backgrounds of prospective jurors. ${ }^{41}$ These detectives looked into each potential juror's life, habits, reputation, and standing in the community. ${ }^{42}$

33. Treason Act, 1708, 7 Ann., c. 21, § 14 (Eng.).

34. 4 WILLIAM BLACKSTONE, COMMENTARIES *351-52.

35. See Commonwealth v. Long, 922 A.2d 892, 902-03 (Pa. 2007) (highlighting the similarities in treatment of juries between the English tradition and early American law).

36. Act of Apr. 30, 1790, ch. 9, § 29, 1 Stat. 118 (codified as amended at 18 U.S.C. § 3432 (2006)). Some states have similar statutes. See, e.g., MASs. GEN. LAWS ANN. ch. 277, § 66 (West 2005); N.H. Rev. Stat. AnN. § 604:1 (2001); see also United States v. Credit, 2 M.J. 631, 640 (A.F.C.M.R. 1976) ("The laws of many of the states provide for the release of lists of persons selected for jury duty prior to trial.... By rule of court in some of the Federal circuits and by Federal statute a more limited right of access to jury lists exists.”), rev'd, 4 M.J. 118 (C.M.A. 1977).

37. Stewart v. United States, 211 F. 41, 46 (9th Cir. 1914).

38. See 3 William Blackstone, Commentaries *355 (stating that "the panel [of jurors] is returned to the court upon the original [writ of] venire, and the jurors are to be summoned and brought in many weeks afterwards to the trial, whereby the parties may have notice of the jurors, and of their sufficiency or insufficiency, characters, connections, and relations, that so they may be challenged upon just cause").

39. RANDOLPH N. JONAKAIT, THE AMERICAN JURY SYSTEM 149-50 (2003).

40. Commonwealth v. Wong Chung, 71 N.E. 292, 294 (Mass. 1904).

41. JonaKait, supra note 39, at 149 (quoting F.A. MacKenziE, THE TRIAL OF HarRy THAW 210 (1928)) (internal quotation marks omitted).

42. Id. 
Renowned attorney Clarence Darrow placed great emphasis on jury selection and relied on investigators to learn about prospective jurors. ${ }^{43}$ In the trial of Bill Haywood, both Clarence Darrow and the prosecution "were amply equipped with precise intelligence gathered during the massive effort both sides had expended to compile the preferences, affiliations, and dirty little secrets of hundreds of potential jurors. Both sides had sent small armies of scouts into the countryside posing as insurance men, encyclopedia salesmen, and other itinerants." 44

During the 1920s, Professor Clarence N. Callender, as part of an overall study of jury-selection methods in Philadelphia, examined jurorinvestigation methods utilized by members of the Philadelphia bar during both civil and criminal trials. ${ }^{45}$ The Philadelphia City Solicitor and District Attorney relied on the local police, while private litigants turned to detectives and companies that specialized in juror-investigation services. ${ }^{46}$ For a fee, these companies provided attorneys with background information on prospective jurors. ${ }^{47}$

Regardless of whether an attorney used law enforcement, a private investigator, or a juror-investigation service, the information gathered about prospective jurors during this time period was typically the same. ${ }^{48}$ For example, a standard list of questions used by Philadelphia prosecutors in the 1920s asked about the potential jurors' political and religious affiliations, marital status, reputation in the community, drinking and other morality-reflective habits, employment status, and

43. Geoffrey Cowan, The People v. Clarence Darrow 179-80 (1993).

44. JONAKAIT, supra note 39, at 149 (quoting J. ANTHONY LUKAS, BIG TROUBLE: A MuRDER in a SMall Western Town Sets OfF A StRuggle fOR the Soul of America 527 (1997)) (internal quotation marks omitted).

45. Clarence N. Callender, The Selection of Jurors: A Comparative Study of the Methods of Selection and the Personnel of Juries in Philadelphia ANd Other Cities 2730 (1924).

46. Id. at 28-30. Modern companies offer similar juror-investigation services. See, e.g., Pantos v. City \& Cnty. of San Francisco, 198 Cal. Rptr. 489, 491 (1984) (considering the propriety of a juror-investigation service's request for information about prospective jurors).

47. Pantos, 198 Cal. Rep. at 491; Okun, supra note 29, at 851 n.46 (citing MELVIN M. BELLI, 1 Modern TRIALs § 116 (1954)); see also Dow v. Carnegie-Ill. Steel Corp., 224 F.2d 414, 430 (3d Cir. 1955) (discussing the operations of companies that investigate jurors); Melvin M. Belli, Foreword to WiLliam J. BRYAN JR., The ChOSEn OnES, at x (1971) (“In most 'big cities' there are 'jury services.' These are like the 'Winter Book' at Hialeah[, which handicaps the horses for the racing season at the Hialeah racetrack at Florida]. They putatively tell how a juror will 'run.' At least some information is given as to his religion, his political party, [and] how he voted in other cases.").

48. See CALLENDER, supra note 45, at 28-29. 
criminal history. ${ }^{49}$ Of course, the attorneys welcomed any other remarks or observations from the investigators. ${ }^{50}$

Because criminal statutes and ethical rules prohibit direct contact with jurors before and during trial, both public and private investigators practiced their craft by reviewing jury books, ${ }^{51}$ researching newspapers and public archives, ${ }^{52}$ consulting other attorneys, ${ }^{53}$ conducting "drivebys" of jurors' residences, ${ }^{54}$ speaking with neighbors of jurors, ${ }^{55}$ and following jurors throughout the day. ${ }^{56}$ One may term the last three methods as "field investigations."

Going to a prospective juror's residence yielded information about the juror's general lifestyle and socioeconomic background. ${ }^{57}$ According to one experienced litigator, an attorney "can learn a lot about [potential] juror[s] by driving by their house[s] and checking out their home environment[: A]re there children's toys in the yard? How many cars [are] in the driveway? What make and model?"58 Two prominent jury consultants even created a "Drive-by Checklist.",59

Speaking with a juror's neighbors or acquaintances offered insight into the juror's “opinions, personal habits, [and] general lifestyle.”60 For attorneys looking to strike prospective jurors with certain personality traits, this information was of high value; ${ }^{61}$ however, it came with risks. ${ }^{62}$ A primary concern was that the neighbor or friend might inform the juror about the questioning. ${ }^{63}$ This, in turn, could sour the juror on jury

49. Id. at 28 .

50. Id.

51. Okun, supra note 29, at 852 n.51.

52. IRVIng Younger, Jury Selection, in The IRVING YOUNGER COLLECTION: Wisdom \& WiT FROM THE MASTER OF TRIAL AdVOCACY 311, 335 (Stephen D. Easton ed., 2010).

53. Hamer v. United States, 259 F.2d 274, 280 (9th Cir. 1958).

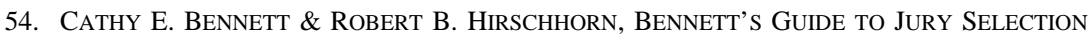
AND TRIAL DYNAMICS IN CIVIL AND CRIMINAL LiTIGATION § 9.2 (Eda Gordon ed., 1993).

55. Commonwealth v. Allen, 400 N.E.2d 229, 238-39 (Mass. 1980).

56. Sinclair v. United States, 279 U.S. 749, 754 (1929). The Court actually condemned this practice. Id. at 764-65.

57. BLUE \& HIRSCHHORN, supra note 30, § 9:1.

58. Paula L. Hannaford, Safeguarding Juror Privacy: A New Framework for Court Policies and Procedures, 85 JUDICATURE 18, 22 (2001) (internal quotation marks omitted).

59. BENNETT \& HiRSCHHORN, supra note 54, app. 9A.

60. Jonathan M. Redgrave \& Jason J. Stover, The Information Age, Part II: Juror Investigation on the Internet-Implications for the Trial Lawyer, 2 SEDONA CONF. J. 211, 212 (2001).

61. See BENNETT \& HIRSCHHORN, supra note 54, § 9.1.

62. See BluE \& HirschHORN, supra note 30, § 9 intro. (noting expense, time, and psychological impact as potential risks).

63. See Commonwealth v. Allen, 400 N.E.2d 229, 233 (Mass. 1980); see also BLUE \& 
service, skew her views of the attorneys, or alter her decision-making process in the case. ${ }^{64}$

In Commonwealth v. Allen, the court examined the concerns that arose when an attorney conducted interviews of prospective jurors' neighbors and friends. ${ }^{65}$ The trial judge and defense counsel discussed the judge's misgivings with this process at length. ${ }^{66}$

[Trial] judge: "You have conducted interviews in the neighborhoods where the jurors were from?”

Counsel for [Defendant]: "Yes, your Honor."

[Trial] judge: "Don’t you think that’s extraordinarily dangerous?”

Counsel for [Defendant]: "Well, your Honor, I think that, understanding our responsibility and reviewing the statute and reading what authority granted us to exercise our discretion and-within the responsibility of the statute, we carefully made sure we never interviewed any jurors, jurors' families, relatives of any jurors, and I so represent.”

[Trial] judge: “But wouldn't the juror know—couldn't the juror find out that you people were investigating her by the interviewee telling her or him?”

Counsel for [Defendant]: "Quite possibly.”

[Trial] judge: “I think it’s highly unethical.”,67

There is also the possibility that a potential juror may be unintentionally interviewed, which is exactly what occurred in United States $v$. White. ${ }^{68}$ In White, a private investigator employed by the defendant interviewed neighbors of prospective jurors in an attempt to gather information. ${ }^{69}$ In addition, the private investigator accidentally

HIRSCHHORN, supra note 30, § 9:6.

64. As observed by the jury consultant Robert Hirschhorn, "The juror might then go to the other jurors and say, 'You know what that lawyer did, he investigated me.' . . They may think you[] invad[ed] their privacy and think ill of you.” Kay, supra note 8 (internal quotation marks omitted)).

65. 400 N.E.2d at 233-35.

66. Id.

67. Id. at 233.

68. 78 F. Supp. 2d 1025 (D.S.D. 1999).

69. Id. at 1025. 
spoke with a prospective juror. ${ }^{70}$ This fact was not revealed until after the court empanelled the jury, and the judge ruled that such contact threatened the jury's impartiality and ordered selection of a new jury. ${ }^{71}$

Of the field investigation methods employed, tracking or following jurors was arguably the most intrusive. In Sinclair v. United States-the only Supreme Court case to date directly addressing juror investigations - the Court strongly condemned the practice of tracking or following jurors. ${ }^{72}$ In Sinclair, the trial court convicted the defendants of contempt for hiring private detectives to follow the jurors sitting on their trial, even though the detectives never contacted the jurors ${ }^{73}$ and no juror had any knowledge of the detectives' conduct. ${ }^{74}$

In upholding the contempt convictions for three of the four defendants, the Sinclair Court used extremely harsh language to describe the practice of employing detectives to follow jurors. According to the Court, "[t]he most exemplary resent having their footsteps dogged by private detectives. ... The mere suspicion that he, his family, and friends are being subjected to surveillance by such persons is enough to destroy the equilibrium of the average juror and render impossible the exercise of calm judgment upon patient consideration." 75

Despite the holding in Sinclair, attorneys continued to rely on detectives to investigate jurors. ${ }^{76}$ This is because rather than rigidly follow Sinclair, most courts attempted to distinguish it. ${ }^{77}$ For example, some lower courts focused on the timing of the juror investigation. ${ }^{78}$

70. Id. at $1025-26$.

71. Id. at $1026-28$.

72. 279 U.S. 749, 765 (1929). In Batson v. Kentucky, the Court briefly discussed juror investigations, but it withheld any judgment on the topic. 476 U.S. 79, 89 n.12 (1986).

73. 279 U.S. at 760.

74. Id. at 764. Most juror investigations, both then and now, are conducted clandestinely. See Kay, supra note 8.

75. Sinclair, 279 U.S. at 765.

76. See, e.g., Commonwealth v. Allen, 400 N.E.2d 229, 232-39 (Mass. 1980).

77. See David Weinstein, Protecting a Juror's Right to Privacy: Constitutional Constraints and Policy Options, 70 TEMP. L. REV. 1, 36 (1997) ("The strong language of Sinclair rarely has been cited, and the next case to consider the impact of the investigation of jurors on their willingness to serve, United States $v$. Costello, reached a conclusion seemingly at odds with the language of Sinclair." (footnote omitted)). The Second Circuit, in Costello, approved of certain jurorinvestigation practices and, so long as the jurors did not discover the investigation, rejected the claim that such conduct would create a biased jury. United States v. Costello, 255 F.2d 876, 884 (2d Cir. 1958).

78. See, e.g., Dow v. Carnegie-Ill. Steel Corp., 224 F.2d 414, 430-31 (3d Cir. 1955) (distinguishing use of juror-investigation service, which compiled general information about prospective jurors before trial, from constant surveillance of jurors during trial, as occurred in Sinclair). 
These courts more frequently acquiesced to juror investigations that occurred prior to the court's empanelment of the jury. ${ }^{79}$ Other courts concentrated on the purpose of the investigation. These courts generally permitted fact gathering. ${ }^{80}$ In contrast, investigations with the perceived aim of harassing or intimidating jurors were more likely to reach the level of those criticized by Sinclair. ${ }^{81}$

For most of the twentieth century, juror investigations remained relatively static, and the techniques used in the practice continued unchanged. $^{82}$ While the information sought by attorneys expanded beyond areas such as the drinking habits of jurors, the same individuals followed similar procedures to gather it. ${ }^{83}$

Starting in the 1970s, however, the introduction of trial consultants changed the practice. ${ }^{84}$ Private attorneys, especially those with affluent or high-profile clients, started to use trial consultants to research and investigate not only jurors but also the communities from which they were drawn. ${ }^{85}$ This, in some ways, refined the practice of investigating jurors. ${ }^{86}$ Trial consultants also assisted in giving the appearance, if not the reality, that attorneys relied less on hunches and more on scientific reasoning during the selection of jurors. ${ }^{87}$

One should briefly note that trial consultants do far more than investigate jurors. ${ }^{88}$ In fact, juror investigations are just a small part of a

79. See, e.g., United States v. Falange, 426 F.2d 930, 932-33 (2d Cir. 1970); Martin v. United States, 266 F.2d 97, 99 (5th Cir. 1959); Costello, 255 F.2d at 883-84; Best v. United States, 184 F.2d 131, 141 (1st Cir. 1950); Allen, 400 N.E.2d at 236-39.

80. See Allen, 400 N.E.2d at 237 (finding an "implied right to use reasonable means to gather information" about prospective jurors before trial).

81. See James J. Gobert et al., Jury Selection: The Law, Art, and Science of SELECTING A JURY § 5:1 (3d ed. 2010) ("The appropriate balance appears to be that as long as jurors are not intimidated, harassed, or contacted directly, juror investigations may be permissible.”).

82. See Okun, supra note 29, at 845-64 (dividing sources of information about jurors into three broad categories and explaining techniques used to gather such material).

83. See id. (describing the investigative practices employed by both private and government attorneys before, during, and after trial).

84. See V. Hale Starr \& Mark MCCormick, JuRy SELEction § 8.06 (3d ed. 2001).

85. Diana G. Ratcliff, Comment, Using Trial Consultants: What Practitioners Need to Know, 4 J. Legal AdVoc. \& PRAC. 32, 41 (2002). This is not to say that prosecutors never use trial consultants; they do. For example, the Maryland State Prosecutor hired a private consultant in the trial of Baltimore Mayor Sheila Dixon. Annie Linskey \& Julie Bykowicz, In Unusual Move, State Employs Jury Consultant, BALT. Sun, Nov. 11, 2009, at 1A.

86. For an excellent discussion of community attitude assessments and demographic analyses, see STARR \& MCCORMICK, supra note 84, §§ 5.01-6.04.

87. Ratcliff, supra note 85 , at 32-34.

88. Id. at 34 . 
trial consultant's duties. ${ }^{89}$ They conduct community surveys, create juror profiles, provide mock trials, and offer trial advice. ${ }^{90}$ Also, many trial consultants interpret and analyze juror answers and mannerisms during voir dire and throughout the trial. ${ }^{91}$

As one might suspect, juror investigations, even with the introduction of trial consultants, historically favored the government over defendants or private litigants. ${ }^{92}$ This is true for a variety of reasons. First, prosecutors rely heavily on law enforcement to gather information about jurors while defense attorneys typically use private investigators. ${ }^{93}$ Most citizens are less likely to refuse to speak to a law enforcement official as opposed to a private investigator. ${ }^{94}$ Second, law enforcement faces fewer restrictions in obtaining information than do private investigators. ${ }^{95}$ Third, the government has access to information such as police databases ${ }^{96}$ and tax returns ${ }^{97}$ that are unavailable to the general public, including private investigators. Although it may come as a surprise to some, the government has reviewed the tax returns of potential jurors in tax-related cases. ${ }^{98}$

Fourth, prosecutors, who appear daily in court, are more likely to compile data about potential jurors on a regular basis. ${ }^{99}$ For example, many prosecutors across the country maintain so-called juror books or "bad juror lists." 100 These contain background information on jurors who

89. See id. ("[T]he use of consultants has expanded well beyond jury selection, now involving all aspects of litigation.”).

90. See id. at 39-43 (discussing generally some of the services offered by jury consultants).

91. Id. at 42 .

92. See John B. Ashby, Juror Selection and the Sixth Amendment Right to an Impartial Jury, 11 CREIGHTON L. REV. 1137, 1154-55 (1978) ("Government attorneys have their own information sources.... This type of information does give the government an advantage over defense attorneys.”).

93. See id. at 1154-55 (discussing the government's use of law enforcement in obtaining information about jurors).

94. Okun, supra note 29, at 853 (discussing the ease with which an FBI agent may acquire information about potential jurors).

95. Id.

96. Id. at $852-53$.

97. United States v. Costello, 255 F.2d 876, 883 (2d Cir. 1958).

98. Okun, supra note 29, at 867-69 (specifically examining this practice in Costello).

99. JONAKAIT, supra note 39, at 150.

100. See, e.g., Gene Trainor, Tarrant DA Allowed to Keep 'Bad-Juror List' Private, FoRT WORTH STAR-TELEGRAM, Oct. 23, 2010, at B02. 
have previously served. ${ }^{101}$ The information ranges from how the juror has decided earlier cases ${ }^{102}$ to whether the juror has a criminal record. ${ }^{103}$

Finally, courts traditionally are less critical of juror investigations conducted by prosecutors than those performed by defense counsel. ${ }^{104}$ In reviewing the reported criminal cases examining juror investigations, courts rarely question or criticize the procedures used by the government. ${ }^{105}$ Even in Costello - in which the government admitted to examining the tax returns of prospective jurors - the court failed to find fault with the government's practices. ${ }^{106}$ The court in Costello appeared to find that selected jurors would welcome a review of their taxes by the government or, at the very least, would not be bothered by it. ${ }^{107}$

Because of the expense and time associated with juror investigations, which only increased after the introduction of trial consultants, the practice fell out of favor with most practitioners. Generally speaking, it was reserved for prosecutors, ${ }^{108}$ high-profile cases, ${ }^{109}$ or affluent

101. Hamer v. United States, 259 F.2d 274, 280-81 (9th Cir. 1958).

102. Id. at 280.

103. See CALLENDER, supra note 45 , at $28-29$.

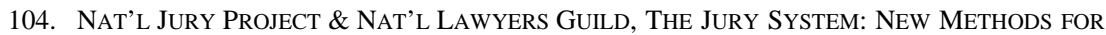
REDUCing PREJUdiCE § 3.3(b)(1) (David Kairys ed., 1975) (“Although investigations by prosecutors are greeted with more permissive language from courts than defense investigations, the authorities acknowledge both the legality and widespread use of juror investigations by all parties.”).

105. See, e.g., cases cited supra note 79.

106. United States v. Costello, 255 F.2d 876, 883-84 (2d Cir. 1958). The court elaborated: Appellant further claims that the practice is against public policy in that, once it becomes generally known, prospective jurors will be intimidated or will attempt to avoid jury duty. These, we incline to believe, are farfetched bogies. Prospective jurors whose returns are vulnerable are the very ones whose elimination is facilitated by the practice: knowledge by the others that they were found acceptable to the Government even after an inspection of their returns would hardly be conducive to their intimidation. And the argument that the practice will tend to discourage cheerful jury service, if of any force at all in view of the mandatory nature of such service, would seem not to apply to those having made honest tax returns.

Id.

107. Id. The court confirmed:

There would seem to be no good reason to believe that knowledge that jury service entails exposure of one's tax return to the scrutiny of a district attorney would deter a good citizen from service in the judicial establishment any more than the fierce publicity which beats upon the private affairs of the citizen appointed to high office in the executive department deters acceptance of such appointment.

Id. at 883-84.

108. Younger, supra note 52, at 334. Professor Irving Younger, who once worked as an Assistant United States Attorney, explained:

It's so expensive, however, that even if you are working for the federal government, you've got to get clearance from a higher level to do this. It was called a name check. You took the list of 500 or so people summoned for jury duty and three FBI agents sat 
defendants. ${ }^{110}$ Unlike the right to counsel, there is no constitutional right to investigate jurors. ${ }^{111}$ This has not stopped some enterprising defense counsel from requesting funds from the court to cover such costs. ${ }^{112}$

Juror privacy rights also played a role in the decline of traditional juror investigations. As concerns about juror privacy started to capture the attention of judges, ${ }^{113}$ academics, ${ }^{114}$ and the public as a whole, ${ }^{115}$ certain jurisdictions made it increasingly difficult to investigate jurors and were less willing to divulge juror information. ${ }^{116}$ Some courts started to wait until the eve or day of trial to release the names of prospective jurors, ${ }^{117}$ while others stopped publicly releasing jury lists or publishing trial dates. ${ }^{118}$ Also, anonymous juries-which allow courts to

and ran those names through the central index. It was before the days of computers, so it had to be done manually. And it took the three agents something like three days. That's nine man-days - that's a lot of money.

Id.

109. See Barbara Allen Babcock, Voir Dire: Preserving "Its Wonderful Power", 27 STAN. L. REV. 545, 559-60 (1975) (noting use of juror investigations by "political defendants").

110. Id. at 662 ("[B]ecause of his limited means, the poor person cannot obtain the information necessary to effect his challenges.”).

111. Nor is there necessarily a state statutory right to recover these costs. See, e.g., CAL. CIV. PROC. CODE § 1033.5(b)(4) (West 2007) ("The following items are not allowable as costs, except when expressly authorized by law:... Costs in investigation of jurors or in preparation for voir dire.”); see also Serio, supra note 1, at 1173-86 (recognizing no constitutional right exists but arguing that one should).

112. Moore v. Johnson, 225 F.3d 495, 501-04 (5th Cir. 2000).

113. See Press-Enter. Co. v. Superior Court, 464 U.S. 501, 512 (1984).

114. See Weinstein, supra note 77 , at 3.

115. See Michael R. Glover, Comment, The Right to Privacy of Prospective Jurors During Voir Dire, 70 CALIF. L. REv. 708, 711-13 (1982) (discussing prevailing concerns regarding the privacy interest of prospective jurors); see also David Doege, New Policy Seals Jurors' Names from Public Record at End of Trial, MilWaukeE J. Sentinel, Sept. 2, 2002, at 1B (noting that "privacy and security" concerns motivated the policy change).

116. See Doege, supra note 115, at 1B.

117. Generally speaking, there is no right to the jury list. See Wagner v. United States, 264 F.2d 524, 528 (9th Cir. 1959); see also Hamer v. United States, 259 F.2d 274, 278-79 (9th Cir. 1958) (discussing Congress's implied decision to withhold juror lists in some cases); Seth A. Fersko, Comment, United States v. Wecht: When Anonymous Juries, the Right of Access, and Judicial Discretion Collide, 40 SETON HALl L. Rev. 763, 771 (2010) (discussing the Hamer court's holding that a court has the authority to withhold juror lists); Laitinen \& Loynes, supra note 5, at 19 ("Some states, for example, do not allow access to potential juror lists until the day that voir dire begins ....”).

118. See, e.g., Mark Ballard, House Panel Backs Bill on Juror Listings, ADVOCATE (Baton Rouge, La.), Apr. 1, 2010, at A4 (discussing Louisiana legislation that would "drop the requirement that newspapers publish the names of jurors and potential jurors”); Teresa Ann Boeckel, Law Experts Disagree on Craver Jury Selection, YoRK DAILY REC. (Pa.), Sept. 1, 2011, at 01/03 (discussing secret jury selection in a murder case); Mick Hinton, House Votes to Shut Lists of Jurors, DAILY OKLAHOMAN, Apr. 21, 1993, at 1 (discussing a bill in the Oklahoma legislature that would close jury lists from public view). 
withhold juror names even from the attorneys trying the case-became more common. ${ }^{119}$

Another reason - though unrelated to juror privacy-for the decline of traditional juror investigations was the shorter period of time that citizens actually served as jurors. Historically, jurors typically served for extended periods of time. ${ }^{120}$ This trend began to shift in the latter half of the twentieth century as courts in cities such as Los Angeles trimmed jury service from thirty days to ten days. ${ }^{121}$ Thus, it became less profitable to research jurors or keep jury books for jurors who only sat for one case as opposed to a series of cases. ${ }^{122}$

\section{B. Modern Approach}

The Digital Age and its advancements in technology have resurrected the practice of investigating jurors. ${ }^{123}$ With the Internet, attorneys no longer need to rely on expensive and labor-intensive field investigations to gather information about jurors. ${ }^{124}$ Today, attorneys or their investigators go online and quickly learn information about jurors. $^{125}$

Online juror investigations take various forms. ${ }^{126}$ At the most basic level, an investigator may perform a name search in a web-based search

119. Nancy J. King, Essay, Nameless Justice: The Case for the Routine Use of Anonymous Juries in Criminal Trials, 49 VAND. L. REV. 123, 130 (1996); see also Abraham Abramovsky \& Jonathan I. Edelstein, Anonymous Juries: In Exigent Circumstances Only, 13 ST. JOHN’s J. LEGAL COMMENT. 457, 458-60 (1999) (discussing the use of anonymous juries).

120. V. HALE StaRR \& MARK MCCORMicK, JURY SELEction § 5.1.02[B] (4th. ed. Supp. 2010) ("By the late 1940s and early 1950s, ... [j]urors usually served on the panel for several months, serving on several trials during their service.”).

121. Sam Enriquez, Trial Consultants: Experts Seek to Identify Jurors’ Bias, L.A. TIMES, Aug. $27,1986, \S 1$, at 1 . "Attorneys and prosecutors once were able to keep track of how jurors voted on previous cases by purchasing so-called jury books. But the books disappeared in Los Angeles after the length of jury service was reduced in 1979 from 30 days to 10 days .... . Id.

122. See id.

123. Peter Vieth, Internet Juror Research Is Revealing, Trained P.I. Can Uncover Even More, VA LAW. WKLY., Nov. 23, 2009, available at http://valawyersweekly.com/2009/11/23/internetjuror-research-is-revealing-trained-pi-can-uncover-even-more/.

124. Id.

125. Id.

126. See Jocelyn Allison, Tweets Let Attorneys Know When Jurors Misbehave, LAw360 (Oct. 23, 2009, 4:18 PM), http://www.law360.com/articles/128603/print?section=topnews (listing Facebook, Twitter, and MySpace as useful tools); Sonia Chopra, Using the Internet and Social Media in Jury Selection, PLAINTIFF MAG. (Feb. 2012), http://www.plaintiffmagazine.com/Feb12/ chopra_using-the-internet-and-social-media-in-jury-selection_Plaintiff-magazine.pdf (discussing the wide array of juror-investigation techniques available because of the Internet). 
engine. ${ }^{127}$ For instance, some attorneys handling capital cases have used these tactics to discover letters to the editor written by prospective jurors about the death penalty. ${ }^{128}$

Many attorneys, however, employ far more sophisticated procedures that include extracting information from blogs, social-networking sites, and online databases. ${ }^{129}$ In California, a defense attorney discovered that a juror deciding his client's fate had blogged about the case during trial. ${ }^{130}$ On his blog entitled "The Misanthrope," the juror posted photographs of the murder weapon and criticized court staff. ${ }^{131}$ The juror's blog even encouraged questions about the case from the general public. $^{132}$

Beyond discovering juror misconduct, attorneys also use online investigations in search of tactical advantages. ${ }^{133}$ For example, a plaintiff's attorney handling a products liability case for a client who suffered injury after being forced to enter a machine to clean it discovered that a potential juror belonged to an online support group for claustrophobics. ${ }^{134}$ Suspecting that this potential juror would sympathize with the plaintiff, the plaintiff's attorney decided to keep this juror on the panel. ${ }^{135}$ The prospective juror ultimately served as foreman, and the plaintiff prevailed at trial. ${ }^{136}$

One unique aspect of online investigations, which distinguishes them from traditional investigations, is the popularity of the practice with news outlets and the general public. Members of the media now routinely investigate jurors in high-profile cases. ${ }^{137}$ In fact, they have become quite adept at uncovering less-than-honest jurors. In the corruption trials

\footnotetext{
127. See Kay, supra note 8 .

128. Id.

129. Laitinen \& Loynes, supra note 5, at 19-20. For a general discussion of various methods of investigating jurors online, see Frederick, supra note 29, at 16-18.

130. Michelle Sherman, The Anatomy of a Trial with Social Media-The Jury, Social MEdiA LAW UPDATE (Dec. 14, 2010), http://www.socialmedialawupdate.com/2010/12/articles/socialmedia/the-anatomy-of-a-trial-with-social-media-the-jury/.

131. Id.

132. Id.

133. Kay, supra note 8 .

134. Id.

135. Id.

136. Id.

137. This phenomenon tracks the popularity among the general public. Ellen Lee, Admit it, You've Googled_Pew Survey Finds Many Have Looked Up Friends on Net, S.F. CHRON., Dec. 17, 2007, at E1. In a survey from 2007, researchers found that "36 percent [of participants] said they have searched the Web for someone with whom [they have] lost touch, and 9 percent have dug up information on someone they were dating." Id.
} 
of former Illinois Governor George Ryan ${ }^{138}$ and Baltimore Mayor Sheila Dixon, ${ }^{139}$ the media discovered discrepancies in the information provided by several jurors that led to the court taking corrective measures.

Besides the media, many in society regularly conduct online investigations. ${ }^{140}$ Although they might use the term "research" as opposed to "investigation," the purpose and end result are usually the same. For example, many individuals before or after meeting a new person either professionally or socially will use web-based tools-like Google or Facebook - to learn more about the individual. ${ }^{141}$ This type of research works because most people have at least one online reference, or "footprint," whether put there personally or by some third party. ${ }^{142}$

\section{Recent Opinions}

To date, in a very limited number of cases, both courts and bar associations have not only approved of online investigations of jurors but also encouraged the practice. In Johnson v. McCullough, the Missouri Supreme Court instructed attorneys that preservation of claims of juror nondisclosure in civil cases requires that an attorney, at a minimum, research jurors on the state's automated case record system prior to the start of trial. ${ }^{143}$

Johnson arose out of a medical malpractice lawsuit brought by a patient against his physician for negligence in treating a throat condition. ${ }^{144}$ During voir dire, plaintiff's counsel asked prospective jurors whether "anyone [had] ever been a plaintiff or a defendant in a lawsuit."145 Numerous members of the panel answered affirmatively; however, one venire member-who was eventually selected to servedid not respond. ${ }^{146}$ After the jury returned the verdict in defendant's

\footnotetext{
138. Michael Higgins, Juror Replacement Is Key to Challenge, CHI. TRIB., Apr. 18, 2006, at C13.

139. Dennis M. Sweeney, Worlds Collide: The Digital Native Enters the Jury Box, 1 REYNOLDS CTS. \& MEDIA L.J. 121, 125-27 (2011).

140. Lee, supra note 137, at E1.

141. Ellen Brickman et al., How Juror Internet Use Has Changed the American Jury Trial, $1 \mathrm{~J}$. Cт. INNOVATION 287, 294 (2008) ("For many Americans ... the natural follow-up to meeting a new person either socially or in business is to search them on the Internet.").

142. Allison, supra note 126.

143. 306 S.W.3d 551, 559 (Mo. 2010) (en banc) (per curiam).

144. Id. at 554 .

145. Id.

146. Id. at $554-55$.
} 
favor, plaintiff's counsel investigated the juror's civil litigation history by using the state's automated system and discovered that she "had been a defendant in multiple debt collection cases and in a personal injury case." 147 Plaintiff's counsel filed a motion for new trial, alleging that the juror "intentionally failed to disclose her prior litigation experience when asked during voir dire." ${ }^{\text {"48 }}$ The judge granted a new trial, and the defendant appealed. ${ }^{149}$

The Missouri Supreme Court upheld the trial court's decision to order a new trial and discussed the responsibility of attorneys to learn information about jurors in future cases. ${ }^{150}$ Specifically, the court found:

[I]n light of advances in technology allowing greater access to information .... it is appropriate to place a greater burden on the parties to bring such matters to the court's attention at an earlier stage. Litigants should not be allowed to wait until a verdict has been rendered to perform [a search on the state's automated case records system] for jurors' prior litigation history when, in many instances, the search also could have been done in the final stages of jury selection or after the jury was selected but prior to the jury being empanelled. ... Until a Supreme Court rule can be promulgated to provide specific direction, to preserve the issue of a juror's nondisclosure, a party must use reasonable efforts to examine the litigation history... of those jurors selected but not empanelled and present to the trial court any relevant information prior to trial. ${ }^{151}$

After the court's decision in Johnson, Missouri began setting aside time to allow attorneys to research jurors prior to the start of trial. ${ }^{152}$

Another example of the modern treatment of juror investigations arose in Carino v. Muenzen. ${ }^{153}$ Like Johnson, Carino involved a claim of medical malpractice. ${ }^{154}$ The plaintiff alleged that the defendant physician failed to timely diagnose a brain hemorrhage. ${ }^{155}$ The New Jersey appellate court held that it was permissible for trial counsel to research prospective jurors in the courtroom during voir dire even though

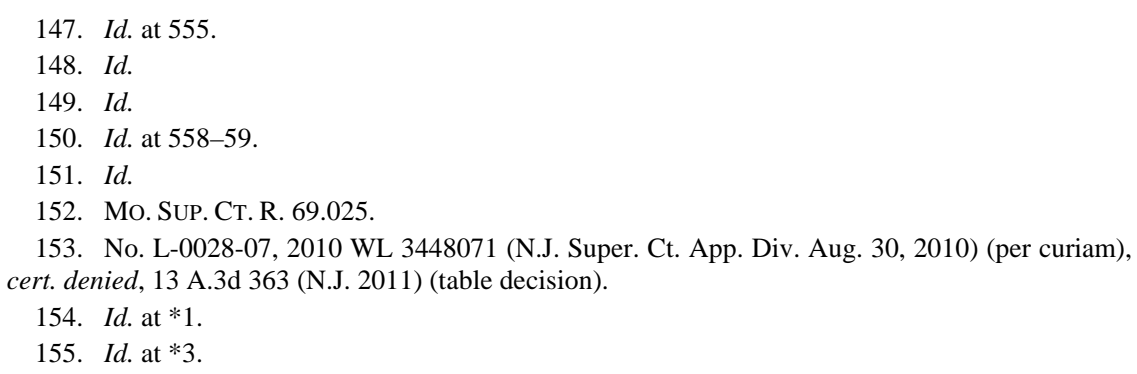


the attorney conducting the research did not provide advance notice to the court and opposing counsel was unable to conduct similar research. ${ }^{156}$

Approximately one year before the start of the Carino trial, the New Jersey court system issued a press release announcing that it would begin offering $\mathrm{Wi}-\mathrm{Fi}$ in the courthouse to "maximize productivity for attorneys." 157 Plaintiff's counsel took advantage of the new Wi-Fi capability by researching jurors on his laptop during voir dire. ${ }^{158}$ Defense counsel, who did not have a laptop, objected to plaintiff's research. ${ }^{159}$ The trial judge sustained the objection, finding that plaintiff's counsel failed to provide notice to either opposing counsel or the court regarding his intent to conduct such research. ${ }^{160}$

The appellate court held that the trial judge had acted unreasonably in prohibiting plaintiff's counsel from using his laptop to research jurors. ${ }^{161}$ The appellate court, however, did not overturn the jury's verdict favoring the defendant because the plaintiff failed to identify "a single juror who was unqualified or as to whom he claims he would have exercised a peremptory challenge, even though he has subsequently had the opportunity to perform an internet search concerning each juror.”"162

In addition to opinions by state courts, local bar associations have also weighed in on the topic of attorneys' researching jurors online. Recently, the New York County Lawyers Association (NYCLA) stated that "[i]t is proper and ethical under [the state's rules of professional conduct] for a lawyer to undertake a pretrial search of a prospective juror's social networking site, provided that there is no contact or communication with the prospective juror." "163 When discussing whether ethical rules allowed attorneys to investigate or monitor jurors after empanelment, the NYCLA was a bit more reserved. ${ }^{164}$ It concluded "that passive monitoring of jurors, such as viewing a publicly available blog or Facebook page, may be permissible."

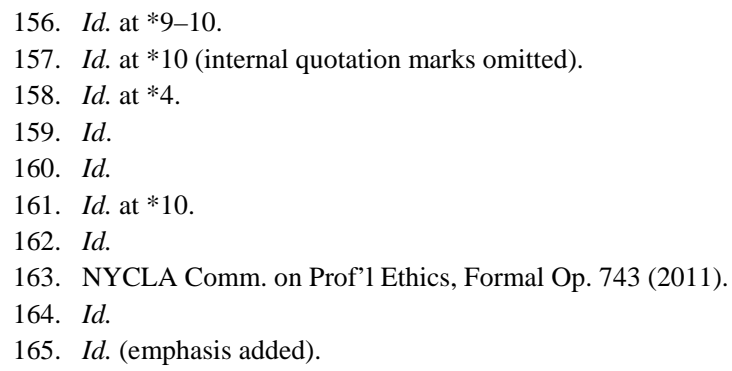




\section{THE BENEFITS OF ONLINE JUROR INVESTIGATIONS}

\section{A. Attorneys}

For a variety of reasons, most attorneys prefer investigating jurors online rather than using traditional methods. First, the Internet offers a significant amount of information about prospective jurors. Some jurors have extensive digital trails or Internet footprints. ${ }^{166}$ With so much information available, sorting through it to find something relevant to the case at hand is a challenge. ${ }^{167}$ As demonstrated, however, by the attorneys defending Jose Padilla - the so-called Dirty Bomber-it is possible, even with a large jury venire, to uncover sufficient information to seek dismissal of a potential juror. ${ }^{168}$

In addition to the vast amounts of information available, some attorneys favor online investigations out of necessity. Courts have reduced the amount of time between when attorneys receive the names of jurors and when the court commences voir dire. ${ }^{169}$ Online juror investigations help to relieve these time constraints. ${ }^{170}$ Even if courts wait until the day of voir dire to release the jurors' names, attorneys may begin and finish their online investigations right in the courtroom. ${ }^{171}$

Other attorneys prefer online investigations because they require fewer resources than traditional field investigations. ${ }^{172}$ As previously discussed, conducting field investigations entails steep financial and labor investments, especially with a large jury pool. ${ }^{173}$ Thus, the average criminal defendant could rarely afford the costs associated with investigating a jury. ${ }^{174}$ This, in turn, expands the representation inequity between affluent criminal defendants and those with limited economic

\footnotetext{
166. See Laitinen \& Loynes, supra note 5, at 17-18 (discussing the various sources of information available online).

167. See id. at 19 (discussing limited time frames as one such challenge).

168. Id. at 18 .

169. See supra notes $117-18$ and accompanying text.

170. GOBERT ET AL., supra note 81, § 5:2 ("Furthermore, Internet juror searches may be the only form of investigation which is practicable when the identity of the jurors does not become known until shortly before trial or at voir dire. Indeed, Internet searches of jurors can even be undertaken while voir dire is in progress.”).

171. Id.

172. Id.

173. See supra notes $39-81$ and accompanying text.

174. See Babcock, supra note 110, at 561-62 (recognizing the inherent limitations on juror investigation facing underprivileged litigants and criminal defendants).
} 
resources. ${ }^{175}$ With online investigations, which require fewer resources, cost is less of an issue. ${ }^{176}$ Attorneys may conduct online investigations in even routine cases where clients lack the financial means to support traditional investigations. ${ }^{177}$ Thus, in a way, the Internet serves to level the playing field by bringing greater economic equality to the representation of criminal defendants. ${ }^{178}$

In addition, unlike traditional investigations that attorneys used almost uniformly for jury selection, online investigations aid in the discovery and prevention of juror misconduct. ${ }^{179}$ For example, online investigations make verifying juror voir dire answers much easier. ${ }^{180}$ Historically, attorneys had few methods by which to prove or disprove statements made by jurors during voir dire. ${ }^{181}$ For example, if a juror falsely claimed that she did not know any of the parties involved in the trial, then the attorney would need to find witnesses or hire a detective to prove otherwise. Today, the attorney may go online to check a juror's voir dire response, which is exactly what occurred in State $v$. Dellinger. ${ }^{182}$

In Dellinger, the West Virginia Supreme Court of Appeals overturned the criminal fraud conviction of a deputy sheriff because of juror dishonesty. ${ }^{183}$ The juror in question did not disclose during voir dire, despite being asked, that she knew the defendant and had a social relationship with the defendant. ${ }^{184}$ Before the trial started, the juror sent the following message to the defendant on a social networking site:

Hey, I don’t know you very well But I think you could use some advice! I havent been in your shoes for a long time but I can tell ya that

175. For a general discussion of the utility of juror information in the jury-selection process, see Richard L. Moskitis, Note, The Constitutional Need for Discovery of Pre-Voir Dire Juror Studies, 49 S. CAL. L. REV. 597, 600-02 (1976).

176. GOBERT ET AL., supra note 81, § 5:4.

177. See Internet Juror Research Can Be Revealing, WIS. L.J. (Nov. 30, 2009), http://wislawjournal.com/2009/11/30/internet-juror-research-can-be-revealing/ (stating that delving into jurors' personal information does not have to be expensive because websites like "Facebook and Twitter provide an abundance of useful information about a prospective juror").

178. GOBERT ET AL., supra note 81 , § 5:2.

179. Laitinen \& Loynes, supra note 5, at 20.

180. See id. at 19 ("[A]n attorney can use social media sites to check the veracity of a potential juror's answers to voir dire questions.”).

181. See GOBERT ET AL., supra note 81, § 5:1 (discussing some of the problems faced in juror investigations).

182. 696 S.E.2d 38, 40 (W. Va. 2010) (per curiam).

183. Id. at 39 .

184. Id. at 40 . 
God has a plan for you and your life. You might not understand why you are hurting right now but when you look back on it, it will make perfect sence. I know it is hard but just remember that God is perfect and has the most perfect plan for your life. Talk soon! ${ }^{185}$

The defendant brought this message to the court's attention after the jury rendered a verdict in favor of the state. ${ }^{186}$ The defendant claimed that he delayed bringing this message forward because he did not initially realize that the person he was communicating with was a juror because she only used her first name. ${ }^{187}$

The enhanced ability to verify jurors' responses also decreases the risk of empanelling a rogue juror. ${ }^{188}$ According to Professor Bennett Gershman, rogue or stealth jurors are those "who seek to inject themselves into the [trial] process for self-serving reasons." issue of heightened concern with high-profile cases. ${ }^{190}$ Traditionally, these jurors could more easily remain undetected because juror investigations provided attorneys with less information than they do today. $^{191}$

Besides uncovering juror misconduct, online investigations prevent it through the monitoring of jurors' online activities during trial. At present, jurors increasingly violate court rules that prohibit researching, blogging, posting, or emailing information about the case. ${ }^{192}$ As jurors learn that counsel may monitor their public, online activities throughout the trial—not just during jury selection-they are more likely to adhere to the court's prohibitions for fear of being caught. One should not

\footnotetext{
185. Id. (errors in original).

186. Id.

187. Id.

188. See Jerry Markon, Jurors with Hidden Agendas-Lawyers See Rise in People Who Don't Disclose Bias, Then Seek to Sway Peers, WALL ST. J., July 31, 2001, at B1 (describing the growing phenomenon of jurors representing themselves as fair while hiding a bias or motivation).

189. Bennett L. Gershman, Contaminating the Verdict: The Problem of Juror Misconduct, 50 S.D. L. REV. 322, 345 (2005).

190. Marcy Strauss, Juror Journalism, 12 YALE L. \& POL'Y REV. 389, $396-99$ (1994) (discussing the potential problems caused by a self-interested juror working to profit from jury duty in high-profile cases).

191. Compare Part II.A (discussing the historical roots of and limitations on juror investigations), with Part II.B (outlining the modern approach to juror investigation and the breadth of information available through online investigations).

192. See Laitinen \& Loynes, supra note 5, at 20 (discussing recent cases that suggest such a trend). For an example of one such court rule, see JUDICIAL CONFERENCE COMM. ON COURT Admin. \& Case Mgmt., Proposed Model Jury instructions: The Use of Electronic TECHNOLOGY to CONDUCT RESEARCH ON OR COMMUNICATE ABOUT A CASE (2009), available at http://www.uscourts.gov/uscourts/News/2010/docs/DIR10-018-Attachment.pdf.
} 
underestimate this benefit in light of the growing number of instances of juror misconduct associated with improper online communication and research. ${ }^{193}$

In one recent study, an English law professor searched the terms "Jury Service" and "Jury Duty" on Twitter. ${ }^{194}$ During a twenty-fourhour period, he viewed over 200 tweets by individuals who appeared to have received a summons to jury duty or actually served as jurors on a trial. ${ }^{195}$ Some of the tweets included information about the individual's experience as a juror. ${ }^{196}$

Finally, online investigations help attorneys bond with jurors. ${ }^{197}$ Online investigations facilitate this connection by providing attorneys with information on issues of specific interest to jurors. ${ }^{198}$ As explained by one seasoned litigator, "a well-placed metaphor in [a] closing argument tailored to a juror's interest or social views as described on Facebook or Twitter" can be quite effective. ${ }^{199}$ Here, of course, the attorney must be careful to avoid the appearance of pandering to a particular juror. $^{200}$

\section{B. Legal System}

It is clear that juror investigations, regardless of the method, provide benefits to attorneys. What is less clear, as this Article explains next, is how improving jury-selection methods benefits the legal system and society as a whole.

193. See Denise Zamore, Can Social Media Be Banned from Playing a Role in Our Judicial System?, MINORITY TRIAL LAW., Spring 2010, available at http://apps.americanbar.org/litigation/ litigationnews/practice_areas/minority-jury-social-media.html (noting that the use of social media creates problems that can escalate to mistrials).

194. Michael Bromby, The Temptation to Tweet-Jurors' Activities Outside the Trial 1 (Mar. 25-26, 2010) (unpublished manuscript) (on file with author).

195. Id.

196. Id. at $1-2$.

197. Laitinen \& Loynes, supra note 5, at 20 (“Attorneys can make use of social media to tailor their opening statements and closing arguments.... If a juror's Facebook page reveals that the person is a 'fan' of a particular environmental group or charity, or that the person is an avid animal lover, when appropriate, a savvy lawyer might be able to use analogies or anecdotes to gain sympathy for a client.” (citing Kay, supra note 8)).

198. Hopkins, supra note 31, at 13.

199. Id.

200. See Kay, supra note 8 (discussing the danger involved with investigating jurors, especially if jurors know they are being investigated). 
For some time, there has been an ongoing debate on whether the United States should follow the British example ${ }^{201}$ and abolish peremptory challenges. Academics, ${ }^{202}$ legal commentators, ${ }^{203}$ and judges $^{204}$ have at one time or another criticized peremptory challenges. The main objection lodged against peremptory challenges decries the method by which attorneys employ them. ${ }^{205}$ Unlike challenges for cause, peremptory challenges allow the removal of a juror despite that juror's impartiality and fairness to both sides. ${ }^{206}$ Attorneys need not offer any reason for using peremptory challenges. ${ }^{207}$ This, in turn, has led attorneys - who often have very little background information on jurors besides what they see and hear in the courtroom - to exercise peremptory challenges based on outdated stereotypes and hunches premised on a juror's physical appearance. $^{208}$

Attorneys with more information about potential jurors are less likely to strike a juror solely because of gender or race, which are both unconstitutional, ${ }^{209}$ or physical size, ${ }^{210}$ which is illogical. Professor Stephen Saltzburg, who has advocated for providing attorneys with more information about prospective jurors, has offered insight into the realities of jury selection. ${ }^{211}$ "[M]ost lawyers resort to stereotypes, not because

201. Criminal Justice Act, 1988, c. 33, § 118 (U.K.).

202. Vivien Toomey Montz \& Craig Lee Montz, The Peremptory Challenge: Should It Still Exist? An Examination of Federal and Florida Law, 54 U. MiAmI L. REV. 451, 453 (2000); see also Morris B. Hoffman, Peremptory Challenges: Lawyers Are From Mars, Judges Are From Venus, 3 GREEN BAG 2D 135, 136 (2000) (“Most law professors don’t like peremptory challenges.”).

203. Brent J. Gurney, Note, The Case for Abolishing Peremptory Challenges in Criminal Trials, 21 HARV. C.R.-C.L. L. REV. 227, 230 (1986).

204. Batson v. Kentucky, 476 U.S. 79, 102-03 (1986) (Marshall, J., concurring); Raymond J. Broderick, Why the Peremptory Challenge Should Be Abolished, 65 TEMP. L. REV. 369, 371 (1992).

205. See, e.g., Batson, 476 U.S. at 102-05 (Marshall, J., concurring) (discussing the use of peremptory challenges to exclude jurors based on race).

206. Albert W. Alschuler, The Supreme Court and the Jury: Voir Dire, Peremptory Challenges, and the Review of Jury Verdicts, 56 U. CHI. L. REV. 153, 170 (1989) ("Peremptory challenges ensure the selection of jurors on the basis of insulting stereotypes without substantially advancing the goal of making juries more impartial.”).

207. Id. at 167-69.

208. Id. at 202 (citing Batson, 476 U.S. at 123 (Burger, J., dissenting)).

209. J.E.B. v. Alabama ex rel. T.B., 511 U.S. 127, 146 (1994) (holding that "the Equal Protection Clause prohibits discrimination in jury selection on the basis of gender"); Batson, 476 U.S. at 89 (holding that the Equal Protection Clause bars the use of peremptory strikes based on race).

210. See Dolphy v. Mantello, 552 F.3d 236, 237 (2d Cir. 2009). In Dolphy, a prosecutor used a peremptory strike on an overweight African-American woman during jury selection for a trial of an African-American defendant. Id. The Second Circuit remanded the case for proper application of Batson. Id. at 237, 239-40.

211. Stephanie B. Goldberg, Batson and the Straight-Face Test: Courts Split on Gender-Based Jury Picks, Permissible Stereotyping, A.B.A. J., Aug. 1992, at 82, 88. 
they want to, but because they have to .... [ [I have] never met a lawyer who would prefer a jury of a particular racial composition over one that will win a verdict for him." ${ }^{212}$ With the additional information gleaned from online investigations, attorneys may exercise peremptory challenges more intelligently and within constitutional constraints. ${ }^{213}$ Peremptory challenges exercised on facts rather than unproven stereotypes give defendants-and society as a whole-greater confidence that the legal system functions properly. ${ }^{214}$

In recent years, obtaining additional information about jurors through traditional voir dire has become increasingly difficult. Numerous courts across the country, citing time constraints, have either reduced the time allocated for voir dire or switched from attorney- to judge-conducted voir dire. $^{215}$ Online investigations help rectify this troubling deficit in juror information. And, unlike other methods of acquiring information about jurors such as extending voir dire, investigations do not delay or lengthen trials. $^{216}$ Since juror investigations, even if conducted in the courtroom, occur outside of the normal trial process, they do not impact the overall length of the trial.

Besides improving the use of peremptory challenges, juror investigations, especially when conducted online, help reduce the

212. Id. (internal quotation marks omitted); see also JONAKAIT, supra note 39, at 149 ("Not surprisingly, lawyers feel that they can use peremptories more effectively when they better know the jury pool.”).

213. Strahilevitz, supra note 6, at 1693 ("If the government . . essentially provid[ed] dossiers on all prospective jurors, [then] one might expect to see less discrimination on the basis of race, national origin, religion, gender, and other immutable characteristics.”). As one practitioner has observed:

Yet in some ways increased juror investigation may show more respect for the individuality of jurors. For years the practice of law has relied heavily on stereotypes during jury selection. Data is published left and right discussing whether married mothers are better jurors than single women for cases against corporations, or whether men over 50 are good picks for a jury trial about Social Security fraud. There is tremendous potential with juror research to step away from classifying individuals by these subcategories. Instead, an attorney can look at a blog and say, juror 12 seems compassionate or juror 12 seems financially savvy. The characteristics of the jurors are determined by their actions online, and not by their membership in a certain classification.

Johnson, supra note 12, at 4.

214. Cf. Susan L. McCoin, Note, Sex Discrimination in the Voir Dire Process: The Rights of Prospective Female Jurors, 58 S. CAL. L. REV. 1225, 1241 (1985) ("Discriminatory practices based on stereotypes dilute the public confidence in the jury system.”).

215. New York, for example, requires that the trial judge in a civil case impose "time limitations for the questioning of prospective jurors during the voir dire.” N.Y. COMP. CODES R. \& REGS. tit. 22, § 202.33(d) (2012).

216. See supra Part II.B. 
imbalance between criminal defendants and the prosecution. ${ }^{217}$ With respect to information, the government traditionally held an advantage over the defense because the government has access to information that is not readily available to the general public. ${ }^{218}$ Further, government resources generally surpass even the most affluent defendant. ${ }^{219}$ Online investigations of jurors, which require far fewer resources than traditional investigations, offer even indigent defendants the opportunity to reduce this information disparity. ${ }^{220}$

Finally, one should note that online pretrial investigations can improve judicial economy by limiting later appeals or claims of juror misconduct. By requiring attorneys to investigate jurors before trial, the court may reduce the likelihood of post-verdict claims of juror misconduct because attorneys should discover potential issues earlier in the process. At least one state has required attorneys to investigate jurors before trial or forego later claims of juror misconduct. ${ }^{221}$

\section{THE DisADVANTAGES OF ONLINE JUROR INVESTIGATIONS}

\section{A. Juror Privacy}

One major concern with online juror research is the potential for encroachment on juror privacy. Judge Posner recently stated that "[m]ost people dread jury duty - partly because of privacy concerns."222 Some believe that this dread will become more acute and cause the national jury summons reply rate to fall even lower as jurors realize that, in addition to answering very personal questions during voir dire, they must submit to online investigations. ${ }^{223}$ Others worry that online investigations may interfere with jurors' abilities to perform their

217. See supra notes $92-107$ and accompanying text (discussing the imbalance created by the cost of traditional investigation).

218. See supra notes $92-107$ and accompanying text.

219. See supra notes $92-107$ and accompanying text.

220. See supra Part II.B.

221. Johnson v. McCullough, 306 S.W.3d 551, 554 (2010) (en banc) (per curiam).

222. United States v. Blagojevich, 614 F.3d 287, 293 (7th Cir. 2010) (Posner, J., dissenting); see also Strahilevitz, supra note 6, at 1694 ("Jury duty is already viewed as an unappetizing prospect for many Americans, and the loss of privacy associated with comprehensive government background checks could prompt stiff resistance and exacerbate juror absenteeism.”).

223. See John E. Nowak, Jury Trials and First Amendment Values in "Cyber World", 34 U. RICH. L. REV. 1213, 1247 (2001) ("[T]he thought that one's entire life will be open to the government and public through jury service certainly may well deter most people from wanting to serve on a jury.”). 
duties. ${ }^{224}$ As discussed below, these fears may be somewhat overblown, especially with respect to younger jurors.

On the concept of online privacy, younger jurors, who are generally classified as "Digital Natives," ${ }^{225}$ usually differ with older jurors, who are generally classified as "Digital Immigrants."226 Digital Natives, as compared to Digital Immigrants, are less likely to be surprised or bothered by online investigations. ${ }^{227}$ This is not to say that Digital Natives are unconcerned about online privacy. Rather, Digital Natives worry more about maintaining some "control over who knows what" about them. ${ }^{228}$ These differences between Digital Natives and Digital Immigrants arise in large part because of the experience each generation has had with the Internet. ${ }^{229}$

Digital Natives have grown up with the Internet and are more likely to have been subjected to and conducted their own online investigations. $^{230}$ As previously discussed, in the Digital Age, online investigations occur regularly both in and outside of the courtroom. ${ }^{231}$ In 2009, forty-five percent of employers reported that they used social networking sites to screen applicants. ${ }^{232}$ Also, many in society, even when serving as jurors, conduct online investigations. ${ }^{233}$ Despite receiving admonitions from the judge, some jurors, especially Digital Natives, go online during the trial to find information about witnesses, attorneys, the judge, and the defendant. ${ }^{234}$

224. United States v. White, 78 F. Supp. 2d 1025, 1028 (D.S.D. 1999) ("In the Court's experience, in a criminal drug case such as this, it is not farfetched to expect jurors to feel intimidated by or prejudiced toward a defendant who, they learn, has conducted an investigation of their personal lives by interviewing their next-door neighbors.”).

225. Marc Prensky, Digital Natives, Digital Immigrants Part 1, ON THE HoRIzON, Sept.-Oct. 2001, at 1, 1 (defining a Digital Native as someone who has grown up with the Internet).

226. Id. at 1, 3 (defining a Digital Immigrant as someone who has migrated to the Internet).

227. See infra notes 230-32 and accompanying text (discussing the frequency and commonality of online investigations).

228. Sonia Livingstone, Taking Risky Opportunities in Youthful Content Creation: Teenagers' Use of Social Networking Sites for Intimacy, Privacy and Self-Expression, 10 NEW MEDIA \& Soc'Y 393, 404 (2008). ("This suggests a definition of privacy not tied to the disclosure of certain types of information, rather a definition centered on having control over who knows what about you.”).

229. Prensky, supra note 225, at 3 (explaining that Digital Immigrants "turn[] to the Internet for information second rather than first," like Digital Natives).

230. Id. at 1 .

231. See supra notes $141-42$ and accompanying text.

232. Rosemary Haefner, More Employers Screening Candidates via Social Networking Sites, CAREERBUILDER.COM (June 10, 2009, 4:20 PM), http://www.careerbuilder.com/Article/CB-1337Interview-Tips-More-Employers-Screening-Candidates-via-Social-Networking-Sites/.

233. Laitinen \& Loynes, supra note 5, at 20.

234. Id. ("Attorneys also need to be mindful that jurors, especially tech-savvy millennial or 
Another factor to consider when examining juror privacy is the alternative to online investigations. Traditional investigations, which sometimes involved surveillance by private detectives, were in many ways more intrusive than online investigations. ${ }^{235}$ While an online investigation allows an attorney to learn more about a juror, the process is more discreet and less invasive. Most web-based searches do not involve contacting anyone associated with the juror. ${ }^{236}$ Even if, as suggested below, the court informs the juror beforehand that the attorneys may conduct online investigations, the juror, for the most part, never knows whether it actually occurred. ${ }^{237}$ In contrast, field investigations usually involved face-to-face contact with a juror's friends, neighbors, and acquaintances, which the juror could easily learn about. $^{238}$ For many people, field investigations constitute the more intrusive practice. ${ }^{239}$ This may change in the future, however, as individuals increasingly spend and place more of their lives online. ${ }^{240}$

Also, one should remember that much of the information sought by attorneys through online investigation is publicly available and has been placed on the Internet by the prospective juror. Courts have consistently recognized that individuals have a lower expectation of privacy in information that they themselves make available on the Internet. ${ }^{241} \mathrm{~A}$ Maryland court recently noted that "[t]he act of posting information on a social networking site, without the poster limiting access to that information, makes whatever is posted available to the world at large."242 As for information posted about jurors by third parties, the question becomes whether access by attorneys should differ from access by others, such as landlords and employers. Those concerned with

Generation Y members, will very likely use social media to research the trial lawyers, clients, and witnesses.").

235. Redgrave \& Stover, supra note 60, at 212-13.

236. Some websites, however, do let the user know who has visited that site. Michael Arrington, See Who's Reading Your LinkedIn Profile, TECHCRUNCH (May 10, 2007), http://techcrunch.com/ 2007/05/10/see-whos-reading-your-linkedin-profile/.

237. Redgrave \& Stover, supra note 60, at 217 (“The [I]nternet allows this investigation to take place anonymously.”).

238. United States v. White, 78 F. Supp. 2d 1025, 1028 (D.S.D. 1999) ("Nor is it farfetched to expect at least some of the prospective jurors to have learned about an investigation conducted through their neighbors.”).

239. See BlUE \& HIRSCHHORN, supra note 30, § 9:1 (“Although the jurors' homes are out in public view, it feels uniquely invasive to the jurors, and the judge, when drive-bys are discovered.”).

240. See generally Strahilevitz, supra note 6, at 1688-94 (discussing the privacy implications of emerging Internet technologies on jury selection).

241. See, e.g., Indep. Newspapers, Inc. v. Brodie, 966 A.2d 432, 438 n.3 (Md. 2009).

242. Id. 
protecting juror privacy may enjoy better results by focusing their attention on the individuals who place the information online rather than those who search for it.

Finally, telling jurors in the initial summons about the possibility and purpose of the investigations may somewhat diminish concerns regarding juror privacy. ${ }^{243}$ According to Professor Caren Morrison, informing jurors about online investigations will put jurors on notice and will "restore some autonomy to the jurors." 244 Such disclosure will allow the jurors to "assume responsibility for strengthening their privacy settings on social networking sites, temporarily suspending their blogs, and not posting any incendiary letters to the editor during the duration of their service." 245 Providing jurors with notice also addresses Digital Natives’ most troubling privacy concern: the ability to have some control over who accesses their online information. ${ }^{246}$

\section{B. Disclosing All Disqualifying Juror Information}

Aside from the concerns surrounding privacy and the potential drop in jury-participation rates, another issue-which is the focus of this Article-exists regarding an assumption made about the information uncovered by attorneys during their investigations. Some assume that the discoverer will turn over to the court or release to the public all disqualifying juror information. While this likely occurs in cases where members of the media find the information, this is not necessarily true for those situations in which attorneys make the discovery. ${ }^{247}$ As previously discussed, when attorneys investigate jurors, their goals may differ from merely seating an impartial jury or ensuring a fair trial. ${ }^{248}$ Rather, some attorneys may want to remove unfavorable jurors, learn the interests and viewpoints of sitting jurors, or uncover grounds for an appeal. $^{249}$

\footnotetext{
243. For an example of a letter disclosing to jurors that the attorneys will research their backgrounds, see Caren Myers Morrison, Can the Jury Trial Survive Google?, CRIM. JUsT., Winter 2011, at 4, 9 .

244. Id. at 10 .

245. Id.

246. See Livingstone, supra note 228, at 404-05.

247. See infra notes $249-55$ and accompanying text.

248. See supra notes $23-27$ and accompanying text.

249. See supra notes 23-27 and accompanying text; see also Kay, supra note 8.
} 
An attorney who discovers improper conduct by a juror in voir dire or during trial may decide not to disclose such information to the court. ${ }^{250}$ This is especially true if the conduct by the juror is neither criminal nor fraudulent and if the attorney thinks that the particular juror will be advantageous to her case. ${ }^{251}$ Attorneys have this option because few rules exist today requiring attorneys to reveal such information. ${ }^{252}$ For example, only a small number of states make information about jurors subject to discovery. ${ }^{253}$ Those few states requiring disclosure of juror information generally place the burden solely on the prosecution. ${ }^{254}$ The defense, however, must first initiate a discovery request, which is generally limited to information not found in the public domain. ${ }^{255}$

As for an attorney's ethical obligation to reveal such information, the Model Rules of Professional Conduct have not kept pace with the technological advancements brought by the Digital Age. Further, these rules, for the most part, are unclear as to when an attorney must report a juror to the court. The most relevant and applicable section of the Model Rules reads:

250. See Jeffrey F. Ghent, Annotation, Right of Defense in Criminal Prosecution to Disclosure of Prosecution Information Regarding Prospective Jurors, 86 A.L.R.3d 571, 574 (1978) (citing the common law rule that the defense counsel in a criminal case has no right of access to the prosecution's information regarding prospective jurors).

251. See id. (noting that courts have held that information about a prospective juror's criminal record or other private information does not need to be disclosed).

252. But see id. ("[I]n accordance with an apparent general trend toward the expansion of criminal discovery, there is judicial authority in a few jurisdictions supporting a right of disclosure in cases involving a prospective juror's criminal record or other private information...." (footnote omitted)).

253. See, e.g., State v. Bessenecker, 404 N.W.2d 134, 138-39 (Iowa 1987) (en banc) (limiting access to juror information by county attorneys and requiring county attorneys to disclose to the defense any juror information obtained); Commonwealth v. Smith, 215 N.E.2d 897, 901 (Mass. 1966) (allowing the defense access to juror information obtained by the government); Ghent, supra note 250 , at 574 .

254. See Bessenecker, 404 N.W.2d at 139 (requiring prosecutors to disclose to the defendant any rap sheets on jurors acquired by court order).

255. See Ghent, supra note 250, at 574-75 ("Rule 421(a) of the Uniform Rules of Criminal Procedure makes it the duty of the prosecuting attorney, on the defendant's written request ...., to allow access at any reasonable time to... 'reports on prospective jurors.”'). Jurisdictions not requiring the release of such information by the prosecutor to defense counsel include Florida, Louisiana, and Texas. See Monahan v. State, 294 So. 2d 401, 402 (Fla. Dist. Ct. App. 1974) (holding that the trial court did not err in denying the criminal defendant's request for discovery of juror records); State v. Jackson, 450 So. 2d 621, 628-29 (La. 1984) (denying defendant's appeal because the records did not impact his voir dire), superseded on other grounds by rule, LA. CODE Evid. ANN. art. 404(B)(1) (2011); Martin v. State, 577 S.W.2d 490, 491 (Tex. Crim. App. 1979) ("The State has no obligation to furnish counsel for accused with information he has in regard to prospective jurors." (quoting Linebarger v. State, 469 S.W.2d 165, 167 (Tex. Crim. App. 1971))). 
Lawyers have a special obligation to protect a tribunal against criminal or fraudulent conduct that undermines the integrity of the adjudicative process, such as bribing, intimidating or otherwise unlawfully communicating with a witness, juror, court official or other participant in the proceeding, unlawfully destroying or concealing documents or other evidence[,] or failing to disclose information to the tribunal when required by law to do so. ${ }^{256}$

Applying this rule to two real-life situations demonstrates the lack of consistent ethical guidance in this area. The first is the case of Jose Padilla, ${ }^{257}$ which presents a routine example of juror dishonesty. During voir dire, several of Mr. Padilla's attorneys ran internet searches on prospective jurors as they were called to sit in the jury box. ${ }^{258}$ One defense attorney discovered that a prospective juror had misled the court about her involvement with the criminal justice system. ${ }^{259}$ The attorney disclosed the issue, and the court removed the prospective juror from the venire. ${ }^{260}$

Applying comment 12 of Rule 3.3 to Mr. Padilla's case, it appears that the defense team, upon learning of the juror's dishonest statement, had an ethical duty to inform the court of the information because it was fraudulent. ${ }^{261}$ Thus, the ulterior motives of the defense team, such as the desire to remove a potential guilty vote, were irrelevant because the attorney had an obligation to report the juror's misconduct.

The second scenario involves the previously discussed juror from Michigan who posted information about the defendant on her Facebook page. ${ }^{262}$ In applying comment 12 of Rule 3.3 to this scenario, neither the defense counsel nor the prosecutor had an ethical duty to disclose the juror's Facebook post to the court. ${ }^{263}$ The juror did not commit a fraud or a crime, even though the conduct was improper. This juror, like many

256. Model Rules of PROF'L CONDUCt R. 3.3 cmt. 12 (2008).

257. United States v. Hassoun, No. 04-60001-CR, 2007 WL 4180847 (S.D. Fla. Nov. 20, 2007). In Hassoun, the trial judge granted the attorneys much leeway during voir dire and allowed them to use a large number of peremptory strikes. Id. at *3 n.11-12.

258. Kay, supra note 8.

259. Id.

260. Id.

261. See Model Rules of Prof’L Conduct R. 3.3 cmt. 12 (2008) (noting that Rule 3.3 "requires a lawyer to take reasonable remedial measures, including disclosure if necessary, whenever the lawyer knows that a person... intends to engage, is engaging or has engaged in criminal or fraudulent conduct related to the proceeding").

262. Cook, supra note 17.

263. See Model Rules of Prof'L Conduct R. 3.3 cmt. 12 (2008). 
jurors before her, determined the defendant's fate prior to hearing all the evidence.

One may argue that this juror's actions were in contempt of court and, thus, the attorneys had an obligation to report it. This argument, however, is very tenuous and requires several assumptions. First, one must assume that the judge indeed told jurors to refrain from posting thoughts about the case online. ${ }^{264}$ Second, one must also assume that the judge clearly and accurately instructed the jurors. Third, one must assume that the juror understood the instructions and purposefully violated the court's order. ${ }^{265}$

Mr. Padilla's case and the Michigan case illustrate the disparate results that may occur under the current Model Rules. As online investigations continue to grow in popularity, ${ }^{266}$ it is highly likely that similar examples will arise in the future. At present, the legal system lacks adequate safeguards to ensure that attorneys disclose all disqualifying juror information. The next section of this Article will examine two proposals to rectify this problem.

\section{PROposed SOLUTIONS}

The two proposed solutions examined in this section require attorneys to disclose certain information uncovered about jurors either to the court or opposing counsel. The first proposal involves a change to the Model Rules of Professional Conduct. The second advocates a change to the Federal Rules of Criminal Procedure and state analogues. Prior to examining these solutions, however, this Article will briefly discuss the merits of requiring attorneys to disclose information discovered about jurors.

264. At present, many jurisdictions have not updated their jury instructions to keep up with changes brought by the Digital Age. Eric P. Robinson, Jury Instructions for the Modern Age: A 50State Survey of Jury Instructions on Internet and Social Media, 1 ReYNolds Cts. \& Media L.J. 307, 307-08 (2011).

265. See, e.g., In re Stoelting, 784 F. Supp. 886, 886 (S.D. Fla. 1992) (finding a juror in contempt and imposing a $\$ 250$ fine because she violated the court's instructions by watching the news concerning the case, forming an opinion on the case, and expressing it to another juror).

266. See Hopkins, supra note 31, at 13-14 (describing the rise of web-based research options). 


\section{A. Reasons to Mandate Disclosure}

The strongest argument for mandating disclosure is fairness. ${ }^{267}$ Both the criminal defendant and the government have a right to a fair trial. ${ }^{268}$ The Supreme Court has recognized that "[o]ne touchstone of a fair trial is an impartial trier of fact." 269 The term "impartial" can at times be difficult to define, especially as applied to jurors. ${ }^{270}$ One indicator of impartiality is the ability to keep an open mind during the presentation of the evidence. ${ }^{271}$

In applying this standard to the conduct of the Michigan juror who posted comments about the trial on Facebook, it becomes fairly clear that she was not impartial. After one day of trial in which she heard only the prosecutor's evidence, the juror was not only ready to convict the defendant but also relished the opportunity to do so. ${ }^{272}$ Permitting a juror like her to remain on the panel threatens the concept of an impartial jury and does little to facilitate the search for truth. Mandating disclosure of her actions protects impartiality.

Disclosure of juror information also helps level the playing field. This is especially true for defendants because juror investigations have historically favored the prosecution. ${ }^{273}$ Although the Internet significantly reduces this disparity by lowering the barriers to information, the gap still exists. ${ }^{274}$ For example, prosecutors still have access to information unavailable to the general public, ${ }^{275}$ and they are more likely than defense counsel to maintain jury books. ${ }^{276}$

267. Losavio v. Mayber, 496 P.2d 1032, 1034-35 (Colo. 1972) (en banc); People v. Aldridge, 209 N.W.2d 796, 798 (Mich. Ct. App. 1973), invalidated by People v. McIntosh, 252 N.W.2d 779 (Mich. 1977), overruled by People v. Weeder, 674 N.W.2d 372 (Mich. 2004) (per curiam).

268. U.S. Const. amend. VI; see also, Singer v. United States, 380 U.S. 24, 36 (1965) (“[T]he Government, as a litigant, has a legitimate interest in seeing that cases in which it believes a conviction is warranted are tried before the tribunal which the Constitution regards as most likely to produce a fair result.”).

269. McDonough Power Equip., Inc. v. Greenwood, 464 U.S. 548, 554 (1984).

270. Nancy S. Marder, Deliberations and Disclosures: A Study of Post-Verdict Interview of Jurors, 82 IOWA L. REV. 465, 525-26 (1997).

271. Id.

272. See supra notes $16-19$ and accompanying text.

273. Ashby, supra note 92, at 1154-55 (describing prosecutors' use of various law enforcement agencies when collecting information about potential jurors).

274. See supra notes $96-97$ and accompanying text.

275. See United States v. Costello, 255 F.2d 876, 883 (2d Cir. 1958) ("The appellant contends that the trial was unfair in that in exercising its challenges the Government had access to information not available to him or to even the wealthiest defendant.”).

276. See supra notes $99-103$ and accompanying text. 
While there will always be some level of inequity in any adversarial process, the legal system should work to reduce the imbalance as much as possible. ${ }^{277}$ At present, some attorneys remain unaware of juror investigations, while others simply lack the resources to perform such research. ${ }^{278}$ One of the reasons Jose Padilla's legal team discovered the untruthful juror during voir dire is that it had the personnel to conduct the investigation, which is not always the case for criminal defense attorneys. ${ }^{279}$ Requiring the disclosure of juror information helps reduce the inequality between parties.

Finally, disclosure helps maintain society's confidence in the legal system. This occurs in two distinct ways. First, requiring attorneys to disclose information discovered about jurors demonstrates that online investigations are not used solely to benefit one attorney over another or as a litigation tactic. Second, allowing concealment of juror information discovered by attorneys may lead some to question the legitimacy of the criminal justice process and ask whether a criminal trial is more about finding information on jurors than a search for the truth. ${ }^{280}$ One legal commentator has noted that "[w]hen both the prosecution and the defense can resist discovery of juror information, it is possible for members of the community to view the result of the trial as dependent upon which side enjoyed the advantage of juror information rather than upon impartial jury deliberations."281

Those opposing disclosure of juror information in criminal proceedings suggest that it is contrary to the nature of the adversarial process. ${ }^{282}$ This antiquated argument does not reflect the modern trend in criminal procedure to allow broad disclosure in the form of discovery. ${ }^{283}$ Furthermore, this argument, traditionally applied to information about

277. Babcock, supra note 110 , at 562 .

278. Professor Hans Zeisel, a jury research expert, identified this potential problem with juror research by observing that "I hate things that benefit the richer side.... One side obtains an advantage over the other. If this thing gets out of hand, [then] the courts might begin to say that you have to disclose whatever you have learned to the other side.” Tamar Lewin, Business and the Law; Jury Research: Ethics Argued, N.Y. TimES, Mar. 9, 1982, at D2 (internal quotation marks omitted).

279. See, e.g., Ken Armstrong \& Justin Mayo, Frustrated Attorney: 'You Just Can't Help People,' SeAttle Times, Apr. 6, 2004, http://seattletimes.nwsource.com/news/local/ unequaldefense/stories/three (detailing a public defender's overwhelming caseload).

280. See Moskitis, supra note 175, at 633-34. Such concealment "creat[es] the appearance of bias" and "erodes community confidence in the jury trial as part of the administration of criminal justice.” Id.

281. Id. at 626 .

282. See id. at 627.

283. See id. at 629 (discussing the "liberaliz[ation of] criminal discovery"). 
witnesses and defendants, lacks support in the context of information about jurors. First, as discussed below, the proposals suggested in this Article are not a "one-way street." Rather, they require disclosure by both the prosecution and defense. ${ }^{284}$ Second, revealing information about jurors, as opposed to information about witnesses, neither puts any individual in harm's way nor facilitates or encourages parties to fabricate evidence. $^{285}$

The work-product privilege provides the strongest argument against revealing juror information obtained by attorneys. ${ }^{286}$ Generally speaking, this privilege prevents the disclosure of an attorney's opinions, theories, or conclusions of law to opposing counsel. ${ }^{287}$ Even assuming that the disqualifying juror information fell under the work-product privilege, the privilege is qualified, not absolute. ${ }^{288}$ Thus, the court could override the privilege. Also, the work-product privilege should not serve as justification for an attorney to withhold information crucial to empaneling and maintaining an impartial jury, just as it would not prevent the prosecution from disclosing exculpatory information to the defense. ${ }^{289}$

\section{B. Methods for Enforcing Disclosure}

\section{Amending the Model Rules of Professional Conduct}

One possible solution to the problem identified in Part IV.B of this Article is to modify the Model Rules of Professional Conduct. For example, an amendment to comment 12 of Rule 3.3 could require attorneys to disclose any improper conduct by jurors. Some states, like

284. David W. Louisell, Criminal Discovery: Dilemma Real or Apparent?, 49 CALIF. L. REv. 56, 58 (1961) (arguing that "any just system of discovery presupposes its equal availability to all adversaries").

285. See Moskitis, supra note 175, at 628 (stating that information in pre-voir dire discovery rarely relates to the defendant).

286. Ghent, supra note 250, at 576 ("One of the most successful prosecution arguments ..., although it has not always been made, is that the information sought was protected from disclosure because it was the prosecutor's 'work product.”').

287. FED. R. CIV. P. 26(b)(3).

288. See id. (allowing that a showing of "substantial need" and "undue hardship" will overcome the privilege).

289. Brady v. Maryland, 373 U.S. 83, 87-88 (1963). 
Tennessee, have taken such action. ${ }^{290}$ Other states have looked to Model Rule 3.5 and modified it to cover acts of juror misconduct. ${ }^{291}$

The main concerns with relying on ethical rules are institutional competence and enforcement. ${ }^{292}$ State bar authorities have very little experience dealing with jurors. This in turn makes it difficult for the bar to determine what information that attorneys uncover about jurors falls within the disclosure requirements. In contrast, the courts regularly deal with jurors, and judges routinely interact with them. ${ }^{293}$ More importantly, judges, after reading a juror's questionnaire and hearing a juror's answers during voir dire, regularly determine whether a particular juror can be impartial or whether an attorney may challenge that juror for cause. ${ }^{294}$

Besides the judge's unique relationship with jurors, there is the issue of enforcement. Courts handle attorney disclosure daily through discovery. ${ }^{295}$ It is the rare criminal case where attorneys do not disclose information through this process. As a result, courts have established "case law and rules of procedure specifically tailored to redress any discovery violations." 296

In contrast, the state bar has very little practice in this area. Moreover, the bar has hesitated to investigate, much less enforce, criminal discovery rule violations. ${ }^{297}$ In sum, the rules of ethics are a good start, at least for those states that have taken those steps. The rules

290. Tennessee is one of the few states that has a much more expansive rule. TENN. RULES OF PROF'L CONDUCT R. 3.3(i) (2011) (“A lawyer who, prior to conclusion of the proceeding, comes to know of improper conduct by or toward a juror or a member of the jury pool shall report the improper conduct to the tribunal, even if so doing requires the disclosure of information otherwise protected by [the attorney's duty of confidentiality].”).

291. See, e.g., Minn. Rules of Prof’L CONDUCT R. 3.5(f) (2011) (“A lawyer shall reveal promptly to the court improper conduct by, or by another toward, a juror or prospective juror or a member of the family thereof, of which the lawyer has knowledge.”).

292. R. Michael Cassidy, Plea Bargaining, Discovery, and the Intractable Problem of Impeachment Disclosures, 64 VAND. L. REV. 1429, 1460-65 (2011).

293. See Cassandra Burke Robertson, Judging Jury Verdicts, 83 TUL. L. REV. 157, 173-79 (2008) (discussing the relationship between judge and jury).

294. Id. at 176 (citing 9B ChARLES Alan Wright \& ARTHUR R. Miller, FEDERAL PraCtiCE AND PROCEDURE $§ 2482$ (3d ed. 2008)). In fact, the Supreme Court has even deferred to a trial judge's determinations of impartiality. Mu’Min v. Virginia, 500 U.S. 415, 433 (1991) (O’Connor, J., concurring) (acknowledging past decisions allowing "special deference” in this context (quoting Patton v. Yount, 467 U.S. 1025, 1038 (1984)) (internal quotation marks omitted)).

295. In re Attorney C, 47 P.3d 1167, 1173-74 (Colo. 2002) (en banc).

296. Id.

297. Cassidy, supra note 292, at 1460-61. 
of discovery, however, provide the most effective tool to ensure disclosure of juror information.

2. Modifying the Rules of Discovery Under the Federal Rules of Criminal Procedure and State Analogues

The second possible solution, and the one favored by this Article, is to modify the rules of criminal procedure and subject information about jurors to the rules of discovery. The new rule proposed by this Article would read as follows:

Any attorney who discovers or learns of information before, during, or after trial that would disqualify a juror from serving, or serve as sufficient grounds for challenging the juror for cause, shall turn over such information to the opposing party.

This rule requires attorneys to treat information uncovered about jurors like other discovery material. For example, a defense attorney-in addition to requesting that the prosecution turn over witness statements, police reports, physical examinations, and other discoverable evidencemight also seek discovery of "any and all information uncovered about the jury venire to support a challenge for cause." The government could make a similar request in its reciprocal discovery motion because this rule applies equally to both sides.

This rule is not all encompassing, however. In fact, the rule would not impact most of the information uncovered about jurors. This is because it covers only select juror information. To be discoverable, the information must be significant enough to support a challenge for cause or otherwise disqualify the juror.

A more comprehensive rule that covered all juror information discovered by an attorney would arguably further reduce the inequality that can arise when only one side investigates jurors. ${ }^{298}$ Complete disclosure would also likely strengthen community support for the trial process and ease some of the privacy concerns that arise with online investigations. $^{299}$ Creating such a broad rule, however, has serious collateral consequences. Most noticeably, requiring the disclosure of all

298. See Moskitis, supra note 175, at 607-24 (discussing many of the issues associated with investigations conducted by only one side); see also Nowak, supra note 223, at 1225 ("The attorney with information about cyber activities of potential jurors will be able to use jury challenges for cause, and use preemptive challenges, in a strategically wise manner.”).

299. See supra notes 222-24 and accompanying text. 
juror information will deter attorneys from even conducting investigations. ${ }^{300}$ Attorneys will have little incentive to investigate jurors if they must reveal all of the information uncovered to opposing counsel. ${ }^{301}$ This in turn harms attorneys and the legal system as a whole because online investigations are beneficial to both. ${ }^{302}$

The rule proposed by this Article is a compromise among competing interests. It is narrowly tailored to keep attorneys interested in conducting online investigations, while sufficiently broad to prevent attorneys from concealing information about biased or partial jurors who should not serve.

\section{CONCLUSION}

The Digital Age, through its advancements in technology, has both resurrected and reshaped the practice of investigating jurors. No longer is it restricted to high-profile cases or affluent clients. Nor is it used merely for purposes of jury selection. Today, attorneys routinely gather a wide assortment of information about jurors for use at different stages of the trial.

While some see online investigation as an intrusion into jurors' personal lives, others believe attorneys, like everyone else, should have access to this information, especially when it is in the public domain. Proponents of this practice point to its tremendous upside and claim that the information uncovered will increase the likelihood of empaneling impartial jurors. In addition, they argue that online investigations reduce instances of juror misconduct. This point incorrectly assumes attorneys will disclose all disqualifying information about jurors. Subjecting such information to the rules of discovery will correct this misconception and help curb some of the criticism aimed at the investigation of jurors.

300. GOBERT ET AL., supra note 81, § 5:12 (“One negative effect of allowing discovery of juror investigations by consultants is that it might have an inhibitory effect on using jury consultants and social science experts in jury selection. If discovery were ordered, then the advantage to be gained might no longer be seen as justifying the expense.”).

301. Id.

302. See supra Part III. 